\title{
Romania's Rural Environment from Shadow Economy to Sustainable Tourism Development
}

\author{
Adeline Cristina Cozma ${ }^{1}$ and Monica Maria Coroș ${ }^{2}$ \\ 1)2) Babeș-Bolyai University, Cluj-Napoca, Romania. \\ E-mail: adeline.cozma@econ.ubbcluj.ro; E-mail: monica.coros@ubbcluj.ro
}

\begin{abstract}
Please cite this paper as:
Cozma, A.C. and Coroș, M.M., 2021. Romania's Rural Environment from Shadow Economy to Sustainable Tourism Development. In: R. Pamfilie, V. Dinu, L. Tăchiciu, D. Pleșea, C. Vasiliu eds. 2021. 7th BASIQ International Conference on New Trends in Sustainable Business and Consumption. Foggia, Italy, 3-5 June 2021. Bucharest: ASE, pp. .... DOI:

$10.24818 /$ BASIQ/2021/07/104
\end{abstract}

\begin{abstract}
Romania is known all over the globe for its high crime in illegal deforestation. From cold-blood killing of the ones who try to protect the forests, to shell companies involved in exporting the wood that has been illegally cut down, the wooden-mafia is present not only in Romania, but also in Brazil, Indonesia Cambodia, Philippines, Cameroon etc. But this natural resource can also be exploited in another manner. Tourism is presented as an alternative, but sustainable solution to exploiting the forestlands. By comparing Romania to Austria, tourism proves to be an effective, long-term, durable activity for counties that are not engaged in illegal affairs, but which are interested in the well-being of their nation. This study aims to demonstrate the influence of economic and financial crime on deforestation and to identify more durable alternatives to excessive logging, using a mix of literature review and desk analysis, enriched by a quantitative research based on secondary data. It may help stakeholders at all levels involved in rural development or in preventing and combating illegal deforestation to better understand this phenomenon and to consider a new perspective: sustain tourism development in order to reduce deforestation. The parallel between Romania and Austria emphasizes its effectiveness and great benefits, and also represents a novel approach of the fight against the underground economy in the rural environment, respectively it provides sustainable solutions for the integration of endangered forestlands in tourism activities.
\end{abstract}

\section{Keywords}

Shadow economy; Wooden mafia; Rural mountainous destinations; Romania; Illegal logging; Sustainable tourism development, Austria.

DOI: 10.24818/BASIQ/2021/07/104

\section{Introduction}

Shadow economy, informal economy, hidden and underground economy, respectively crime economic activities have been a fact of life for a long time, today they are an increasing part of the economic reality in most parts of the world, having a smaller economic impact in the case of advanced economies and affecting more severely emerging economies (Kelmanson, et al., 2019). Due to their spread at international level, governments and international organizations are making efforts to control their extension and impacts in most societies (Schneider and Enste, 2002). Many researchers and academics have become interested in approaching the various levels of shadow economy from both theoretical and practical perspectives. As the same International Monetary Fund (IMF) specialists (Schneider and Enste, 2002; Kelmanson, et al., 2019) explain, there are many potentially serious consequences that can derive from such practices. One negative effect is linked to the fact that a flourishing shadow economy leads to unreliable statistics related to unemployment, labor force, income, and consumption, which eventually determine the development and implementation of economic policies and programs that rely on unrealistic data and, thus, fail responding to real societal needs. Another threat is the destructive cycle that can be generated by the growth of the shadow economy, namely that by tax 
evasion, transactions in the shadow economy keep the states' tax revenues below what would be considered the normal level of tax-collection, thus determining authorities to increase tax rates which eventually leads to more tax-evasion, putting on the long run a higher pressure on public budgets but also on private enterprises, as well. Moreover, public budgets that face shortages, consequently, provide fewer and poorer public services, such as education and training programs, social and welfare services, medical services, and are often associated with societal poverty. Further, another negative impact is the fact that an increasing shadow economy can be associated to an increasing attractivity for both domestic and foreign workers to move away from officially registered jobs to shadow employment opportunities. On short term such jobs seem to be more attractive from the point of view of the provided wages but on the long run expose employees to more insecurity and make them more vulnerable. Furthermore, not only public institutions and services are affected by shadow economic activities, enterprises also face challenges, particularly in terms of innovation and productivity. Moreover, the labor market is also significantly impacted by such practices, as on one hand societies confront high unemployment rates, in economic environments that are unable to provide training services and reconversion opportunities, where states prove to be incapable of developing appropriate and effective labor policies, while on the other hand employees face low motivation levels and little engagement, due to the perceived insecurity. At the same time, businesses confront limited access to financial resources, thus, investments, expansion, and innovation are severely threatened.

Aiming at diminishing its spread, international organizations and state governments struggle to uncover and measure the economic activities that take place in the parallel economy but this remains a very difficult task to achieve. IFM evaluations show that the underground economy as percentage of official GDP is relatively stable. Thus, for the $1988-2000$ timeframe it was estimated at $35 \%$ to $44 \%$ in the case of developing economies, at $21 \%$ to $30 \%$ in that of transition economies, and between $14 \%$ and $16 \%$ for OECD countries (Schneider and Enste, 2002). By 2016, the shadow economy was considered significant in many European states, accounting for less than $10 \%$ to more than $40 \%$ of the GDP, with the lowest levels in the case of advanced economies (10\% to $20 \%$ ), followed by emerging economies $(30 \%$ to $35 \%$ ), and with the highest quota (above $40 \%$ ) in the case of the Community of Independent States (CIS), countries of the former Soviet Union (Kelmanson, et al., 2019, pp. 6-7).

Corruption is closely linked to underground economic activities and, obviously, emerging economies are more affected by corruption than advanced ones. The World Bank defines corruption as the misuse or abuse of public office (by civil servants or elected officials) for private gain. The same institution's specialists identified the following tools of corruption: bribery, theft, political and bureaucratic corruption, isolated and systematic corruption, respectively corruption in the private sector (The World Bank Group, 2017, p. 12). It is considered that during the past years, Romania has managed to improve its CPI position, seeming to have managed to adopt and implement some successful measures regarding the anti-corruption fight but, despite all of these measures, it still performs poorly (The World Bank Group, 2017). Corruption reaches all levels of the Romanian society, starting from the top central public institutions and spreading to the level of local public authorities, health institutions, educational organizations, contaminating all fields of activity both in the public and private sectors, including small and medium-sized enterprises (SMEs).

According to Transparency International (2021a) Romania remains one of the most corrupt country from among the European Union (EU) states. The score of 44 points on a scale totaling 100 points (where 100 signifies "clean", while 0 means "very corrupt") places Romania on the $69^{\text {th }}$ worldwide position out of 180 countries and territories considered in the most recent ranking, of 2020. The same score has also been registered by Bulgaria and Hungary, while the European Union registered an average score of 66 points out of 100, being the most performing region in terms of Corruption Perceptions Index (CPI). Croatia scored also very low (47/100 points). Furthermore, Western and Northern European states proved to be top performers, with Denmark scoring best (88/100 points), followed by: Finland, Sweden, and Switzerland, each scoring 85/100 points. Romania does not only perform low on the CPI but is also remarked for its healthcare expenditures which are below the EU average; furthermore, the underfunding of the medical system has led to another reality of the country, namely brain drain, translated into severe shortages of medical personnel (Transparency International, 2021b). 
In Romania's case, the urban and rural spaces are affected by both corruption and shadow economic activities. This is perhaps one of the main reasons why disparities still persist both among the country's counties organized under the eight regions of development and also between the urban and small towns and rural areas. Some destinations seem to be doomed to remain poor and underdeveloped, while certain urban concentrations have managed to advance significantly. Of special interest for the present paper are Romania's rural destinations from mountainous areas, which on one hand are among the country's most attractive tourist destinations, and on the other hand are host to some of the worst economic criminal activities, illegal wood exploitation, which are not limited to economic crimes but extend to other criminal deeds, including homicide. Another reality of the Romanian rural space is subsistence agriculture. Furthermore, hospitality services provided in rural and mountain areas seem to also be subject to underground business activities. Moreover, in many destinations, first line politicians are either directly involved in illegal and illicit business activities or tolerate such practices of peer politicians or of interest groups. The paper further develops with a section dedicated to the review of specialized literature, with a presentation of the research methodology, followed by a section dedicated to the main findings and their discussion, and a series of final conclusions.

\section{Review of the Scientific Literature}

Shadow economy is also known as informal, underground, or parallel economy and is an evolving phenomenon that adjusts to the development of new regulations and taxation policies. It is not limited to illegal activities, but it also refers to business practices that rely on not reporting their (entire) revenues from the provision of services, the production of goods or from the exploitation of certain resources; it may also involve monetary or barter transactions. Overall, it is related to business activities that normally are subject to a certain level of taxation, as legally established by state of local authorities (Schneider and Enste, 2002). Jaliu and Răvar (2019) focus on informal economy, pointing towards the fact that it spreads between the modern formal economy and the underground economy, encompassing a large variety organizations and behaviors, reaching many products and services. Based on H.G. Grubel quoted by Mirus and Smith (1997, p.5), the IMF describes four types of shadow economic activities, split into illegal and legal monetary and nonmonetary transactions, which further imply tax evasion and tax avoidance. The first category consists of illegal activities involving monetary transactions and includes: the trade of stolen goods, the production and dealing of drugs, prostitution, gambling, smuggling, and fraud. The second category refers to illegal activities that rely on nonmonetary transactions, such as: the barter of drugs or of stolen and smuggled goods; the production and cultivation of drugs for personal use, respectively theft for one's own use. The third category is that of legal activities that involve monetary transactions, which are further dealt with in terms of tax evasion and tax avoidance. The first sub-type, legal activities that involve tax evasion, refers to unreported revenues generated by self-employment, such as: wages, salaries, and assets resulted from carrying out legal activities such as the production and sale of goods, respectively the provision of certain services. Unemployment is both an effect and also a cause of parallel business activities (Davidescu, 2014), contributing to the vicious circle that catches many players and affects various fields of activity and areas. The second subtype, legal activities involving monetary transactions, that rely on tax avoidance, includes various discounts offered to the organizations' employees and fringe benefits. Finally, the last category, that of legal activities that imply nonmonetary transactions are also split into the same two subtypes: activities implying tax evasion (such as the barter of legal services and goods) and activities that involve tax avoidance (which include all sorts of do-it-yourself work and granting help - mainly under the form of service provision - to family members, neighbors or community members) (Schneider and Enste, 2002).

From among the very many and varied topics related to corruption and parallel economy, the authors' focus falls in the case of the current paper on those aspects that are closely related to the Romanian rural mountainous destinations.

It is well known that the level of corruption and shadow-economy is higher in poor areas. The reasons are many and diversified. According to the International Labor Organization (ILO), informal agricultural employment is linked to the widespread ownership of small agricultural plots (Popa, et al., 2016). At global level, tourism is recognized as a major contributor to poverty diminishment, to disparities' reduction among emerging and advanced economies, but at the same time it is also one of 
the largest sectors with business activities run in the shadow economy (Mitchell, 2010; Rogerson, 2014); tourism is associated to important positive impacts upon the increase of wealth, the improvement of living standards, the creation of business opportunities and workplaces (Din, et al., 2016; Jaliu and Răvar, 2019).

Due to a lack of other options, rural residents often work the land for their own use. But informal work is at least as high in the tourism industry, especially when it comes to rural tourism. It is very rare to arrive at an agro-touristic boarding house where all the workers are legally employed, retributed at the real salary, where all the revenues are registered and taxed, where all authorizations are compliant and valid, etc. This is possible also because most actors are either registered as small, limited liability enterprises or function as sole-entrepreneurs or small family businesses, registered as individual enterprises or authorized persons, respectively as family enterprises or associations. The rural population is even more vulnerable, as they lack access to high-paying jobs and are unable to fully use public and social services (including health services and unemployment benefits). It seems that low incomes and few opportunities are the motives that drive people towards an immoral and illegal behavior when it comes to economic and financial regulations. Bearing all of these aspects in mind, it becomes obvious that orienting towards the development of tourism activity under the umbrella of the "pro-poor concept" is a viable solution. According to Jaliu and Răvar (2019), the concept of "pro-poor tourism" has developed as an approach supporting "tourism development in which the private and public sectors, including development agencies and NGOs, collaborate to ensure that tourism generates significant tangible benefits for the poor (Rogerson, 2014); these benefits may be of economic, but also of social, cultural and environmental nature (Dao, 2017)." Furthermore, building on the findings of Smith (2011), Jaliu and Răvar (2019) explain that the predominance of tourism activities operated in the underground economy can prevent the development and determine, in fact the stagnation of this sector. Such a situation occurs due to several mechanisms such as those identified by Din et al. (2016): distorted competition, as operators taking advantage of lower costs compete against player that comply with rules, regulations and taxation policies, eventually eliminating them from the tourism market; decreases of tax revenues caused by tax evasion and avoidance, which consequently present national and local administrations from making public investments in the development and maintenance of general and tourism-specific infrastructure (public utilities, transport services, tourism information services, etc.); avoidance of labor and health regulations, which drives enterprises towards employing unskilled and untrained personnel, expected to work under improper conditions and exposed to social insecurity both on the short and long term. It becomes clear that informal tourism activities eventually affect all the sectors' stakeholders in a negative way (Kesar and Čuić, 2017). Furthermore, tourism destinations end-up suffering, due to the qualitative decrease of their provided services and to the consequent loss of their attractiveness and image deterioration (Jaliu and Răvar, 2019).

However, many Romanian rural mountain areas have become notorious because they exploit wood, lodging being the primary source of income for villages. The state of the world's justice system and the extent of corruption decide the long-term viability of exploitation of this essential resource: wood. Although there is no official ranking of the power and size of the timber mafia in each region, the news about these organized criminal networks from Brazil, Congo, India, Indonesia, and Romania is constantly broadcast in the media. Romanian timber is illegally exploited in half of the country. Trees are illegally cut even in protected areas and in national and natural parks. Those who cross the timber mafia or try to enforce Romania's forest laws will be punished. Most research on this topic aimed at determining the causes of massive deforestation and scarcely mention the problem of corruption in relation to illegal deforestation. This is a significant contributor to climate change, but it is barely mentioned in the media, which continues to air disturbing reports about the timber mafia and the dire repercussions for those who dared to speak out.

Therefore, tourism and lodging in rural areas are important determinants in the level of shadoweconomy, and, implicitly, in the level of corruption. Among the reasons, the softer implementation of the law by public authorities, the negligible impact of one small firm in the collection of taxes, lower incomes and few opportunities, the poor living conditions, and the lack of proper financial education may cause the visible and observable differences between the level of economic and financial crime in the rural areas versus urban areas. 


\section{Research Methodology}

The methodology used relies on a mix of literature review and desk analysis, enriched by a quantitative research based on secondary data. The study comprises the results of multiple researches and applies them in relation with economic and financial crime in the tourism industry. Variables like Corruption Perception Index, calculated by Transparency International - Corruption Perception Index (2021b), and the shadow economy percentage from GDP, found in the database created by Medina and Schneider (2019), are used to compare two very similar, yet very different countries: Romania and Austria.

Tourism is an alternative for exploiting forests, but it needs the trees alive. With all its shortcomings, tourism can be a sustainable way for exploiting natural resources, with smaller negative impact and bigger revenues in the long run. Attempting to explain the enormous differences between Romania and Austria, especially when it comes to forestland management and development of tourism, other two indicators are used: The Environmental Protection Index (EPI) developed by Yale University and Question 111 (Protecting environment vs Economic growth) from the World Value Survey (WVS) $7^{\text {th }}$ Wave. On one hand, data-driven overview of the state of sustainability around the world is presented by EPI (Yale Center for Environmental Law and Policy and The Center for International Earth Science Information Network (CIESIN) at Columbia University's Earth Institute., n.d.). The EPI ranks 180 nations on environmental sustainability and ecosystem vitality using 32 performance indicators across 11 issue categories. Moving from 0 to 100 on the score scale, the sustainability level increases. On the other hand, the WVS-6 questionnaire is a quantitative research tool which covers 290 questions and measures cultural values, attitudes and beliefs towards gender, family and religion, attitudes and experience towards poverty, education, health and safety, social tolerance and trust, attitudes towards multilateral institutions, cultural differences and similarities between regions and societies (World Values Survey Association (WVSA), 2020). Question 111 is formulated as it follows: "Here are two statements people sometimes make when discussing the environment and economic growth. Which of them comes closer to your own point of view? A. Protecting the environment should be given priority, even if it causes slower economic growth and some loss of jobs B. Economic growth and creating jobs should be the top priority, even if the environment suffers to some extent". The respondents should choose one of the given answers, and the results of applying the questionnaire represent the percentage of people that chose an answer over the other. For these two indicators, the most recent data is used: values for year 2020 .

\section{Findings and Discussion}

Mr Ionuț Dumitru, chief economist of Raiffeisen Bank and former president of the Fiscal Council, points out that the among the main reasons why the underground economy functions, one may firstly identify that of avoiding the payment of taxes, followed by not complying with rules and regulations, namely of not requesting and/or receiving certain types of authorizations. This is particularly the case of hospitality services, where a huge number of players provide food and lodging services without having applied for official ranking certificates. For example, by 2012 only around half of the small and medium-sized lodging facilities (villas, boarding houses, agritourist guest houses, cabins, huts and chalets) were officially ranked, while their total lodging capacity equalized if not outran that of the officially ranked hotels (Coroș, 2015; HoReCa, 2012). Another analysis revealed that towards the end of 2013 in Romania were functioning (and promoting themselves online) at least 1,751 hotels, exceeding by 366 the officially registered number of classified hotels (Cojocea and Coroș, 2013). Furthermore, after having verified whether travel agencies and tour-operators comply with the national regulations, the National Authority for Tourism cancelled until the end of 2016 a number of 1,081 tourism licenses, thus eliminating a third of the intermediaries of travel services from the market due to the fact that they had not presented a valid insurance policy, their coverage against the insolvency risk. By the end of 2016 only 2,602 agencies were legally registered in Romania (Economica.net, 2016). This was the most significant measure adopted by the Romanian officials against the businesses that function illegally in the Romanian tourism industry. Still, in Romania's case several other activities connected to leisure and tourism services are affected by shadow economy, respectively by individuals and businesses that operate illegal and illicit activities. Among these one may notice tourism guides, mountain guides and ski instructors, as well. In 2017, during several rounds of discussions regarding 
the much needed Law of Tourism (finally elaborated in 2018), Mr Marius Florea, national guide, $\mathrm{Mr}$ Mihai Jurca, manager of the Association of Tourism Promotion in Oradea and in the Surrounding Areas, and Ms Alina Giurgiu, the manager of the Tourism Guides' School from Oradea, emphasized the need for establishing a Tourism Police to protect local and national tourism guides against the illegal practices. Basically, the Tourism Police would first of all protect the national heritage and would ensure that the European legal framework is implemented in Romania, too, thus, like in other EU states, only qualified guides should be allowed to practice this profession and to provide guided tours to international groups of tourists and visitors. In spite of all the requests and explanations of the Romanian tourism professionals, Mr Titus Dobre, the minister of tourism at that time, did not consider that the establishment of a Tourism Police would be needed. He mentioned that a better cooperation among the institutions of the state would lead to the diminishment of such issues (Florea, et al., 2017). Occupations such as those of mountain guides and ski instructors involve not only the provision of verified information but, above all, the safety of the client. These professions are also affected by the significant presence of unauthorized practitioners. A previous research revealed that although tourist inns have seized to be officially ranked in Romania by 2005, they continue to be popular types of facilities among local entrepreneurs, who operate both lodging and foodservices under this concept. Nearly a third of the identified inns operate without any official classification certificate (Coroș, et al., 2015). Overall, when it comes to foodservice units the number of owners and managers who do not comply with official rules is even higher and tax evasion situations are even more commonly encountered. Another unethical and illegal practice is that of using personnel that is not legally employed or of paying the workers only the legal minimum wage on the books and then of paying undeclared wages and of imposing extra labor hours.

Potentially, due to the high level of underground economic activities in rural areas, many Romanian rural destinations comprise valuable and highly valuable tourist resources but face significant general and specific infrastructure problems (Coroș and Negrușa, 2014). Another source of such challenges are corrupt local and national public authorities. Examples such as the cases of a former mayor of Lupeni, town, which encompasses Straja ski resort, or that of the former mayor of Constanța, the municipality that comprises Mamaia resort, or the scandals related to corruption deeds of former ministers of tourism have become notorious at national and even international levels.

Many of the situations highlighted in the case of Romania are in fact present in several other European destinations. One of the main causes of this situation is due to the fact the European hospitality sector lacks a unique classification system, respectively that some countries do not implement one at all. Consequently, the lack of a common classification and ranking system has led to the development of a great variety of accommodation facilities and of food service units operating throughout the entire European space. Furthermore, this situation has generated an increasing quota of the shadow hospitality, generated by a too loose and much too flexible legal framework of this sector, which has eventually facilitated the development of the shared economy hospitality players (United Nations \& World Tourism Organization, 1994; European Parliament. Directorate General Internal Policies of the Union, 2007; Coroş, et al., 2015). But the European Union also provides excellent examples of successful destinations that have managed to truly develop in a sustainable way. Such an example is Austria which is a top destination for mountain tourism that relies on excellent and highly diversified and specialized services provided by providers from rural destinations. Moreover, the Austrian tourism industry depends on family businesses (Coroș, 2018).

\section{Tourism - a possible alternative?}

Forests can be exploited in different ways: by cutting down trees or by keeping them alive. Many tourists all over the globe demonstrate a special interest for beautiful green landscapes. Sports and nature-based activities, hiking, birdwatching, or relaxing in a remote area are just a few examples of activities preferred by a large number of tourists. However, sawmills and stumps would ruin the local tourism industry. Romania has a unique and exquisite mix of natural resources, with breathtaking landscapes, protected natural areas, and rare biodiversity. The resources are as good as the infrastructure is disastrous. Romania seems to lack most of the artificial tourism resources, while abounds in natural resources. Of course, the problem is the way in which the country was ran and the difficult and still actual process from communism to democracy, which caused a high level of corruption. For Romania, Austria has been a top destination, especially during the winter. Not because the Carpathian Mountains 
are not beautiful enough to be skiable, but because there is no proper infrastructure. At least not like in Austria. It is not only the infrastructure that is different, but also the fact that "nature protection and sustainable tourism are two issues taken seriously by the authorities, with more than a third of the country's surface being under nature protection. Moreover, Austria is full of national parks and protected areas. Some of the most famous are: Lavanttal area; Nockberge and Millstätter Alpe National Reserve; the largest national reservation, Hohe Tauern National Park, is dominated by Großglockner; Kalkalpen National Park (accessible from Pyhrn-Eisenwurzen); and not only these" (Coroș, 2018).

Romania has the largest area of virgin forests and is in the top-most corrupt countries in the whole European Union. That is certainly a threat to sustainability of natural resources. The forestland in Romania is about 7 million hectares, comprising approximately $30 \%$ of the land area of Romania. With only 4 million hectares of forestland, Austria's forest account for almost half of the total land area. In terms of corruption, Romania scores only 44 points in 2020 in the Corruption Perception Index, while Austria scores 76. Therefore, Romania is $72 \%$ more corrupt than Austria. The shadow economy in 2017 for Romania was estimated to $23 \%$ of GDP, while Austria has only 7\%. The reason for this comparison is because the timber Romania exports to Austria, damaging its natural resources, while Austria creates high added-value from manufacturing the imported timber, protects its natural resources, and exploits them in a sustainable way: through responsible tourism. The largest wood processor in Romania is HS Timber Group, former Holzindustrie Schweighofer. With 5 out of 6 production sites in Romania and one in Germany, and with its headquarters in Vienna, HS Timber Group emphasize on their own website: "we have had strong roots in Romania in particular for many years". DIGI24, a Romanian national news trust, reports that if HS Timber Group were to operate in Austria as it does in Romania, it would have major legal problems. Austrian MEP Thomas Waitz says this after visiting one of the company's factories the other day. He says that HS Timber Group cannot guarantee $100 \%$ that the wood purchased does not come from illegal deforestation. And that's because some of the wood purchased comes from places that can't be checked. Over the years, the company has been constantly accused of illegal activities and the worst is this: an Environmental Investigation Agency investigation in 2018 found that the company was procuring timber from third-party vendors originating from the national parks of Romania. HS Timber Group symbolizes and emphasizes the forest management differences between Romania and Austria.

Two of the most known and used indicators when comes to sustainability and relationship with nature are EPI and Question 111 from World Value Survey. By comparing Romania to Austria, the differences continue to appear, while Romania scores only 64.7 on a scale from 0 to 100 representing the sustainability of the activities in a country, Austria scores 79.6. This means that Austria is $23 \%$ manages to achieve a 23\% higher sustainability level than Romania. Question's 111 from World Value Survey results come with no surprise: Austria opts for protecting the environment, with $59.6 \%$ of the total number of responses, while Romania opts for economic growth and creating jobs, with $49.7 \%$ of the total number of responses, and only $48.7 \%$ for protecting the environment. One possible reason for Romania not noticing that respecting nature is the sustainably way to create economic growth in the long-term is the remnants of communism, that can be found in almost all the aspects of Romania's actual life, even after more than 30 years of democracy. However, Austria is a great example for how tourism can be a sustainable and healthy way for exploiting natural resources, especially wood. Skiing in the Alps would definitely not be the same with sawmills around or, even worse, without trees all around the skiing slopes.

\section{Conclusions}

Worldwide, for many, many years, the total forestland is shrinking and shrinking. This means that the deforestation volume is higher than the afforestation volume. That is not sustainable at all. It contributes significantly to the dangerous evolution of the climate change. The reasons behind it are obvious: money. However, an important part of this money is dirty, simply because the timber mafia is as real as it can be. Corrupt senior officials, politicians, police officers, foresters, private companies, on one hand, and bribery, blood, murders, chopped protected areas, angry locals and activists, barren land fields, on the other hand: this is the picture of "wooden mafia". In order to take proper action, to select the correct and suitable tools for reducing these criminal activities, the whole phenomenon needs to be properly analyzed in a fact-based manner. For a proper image, it is not enough to look for numbers, as 
it is not enough to look around us. It is enough only when looking at both: the numbers and the real life. The importance of the study is to provide a solid quantitative basis to any decision-makers that come across this problem of illegal logging.

The purpose of the study is to demonstrate the influence of economic and financial crime on deforestation. Because illegal deforestation depends a lot on what is legal in a country or not, as presented in the study case comparison between Romania and Austria, and because there is no database with worldwide illegal logging volume, the best way to measure the deforestation activities in a country is through the net forestland conversion rate, meaning the forestland converted in a year divided by the total forestland in that period of time. Corruption and shadow economy are types of economic and financial crimes and are used as indicators for it. Fortunately, in this case, there are accurate and well-known databases with up-to-date information. However, the study comprises 134 countries from all over the globe, with huge demographic, cultural, economic, technological, political, sociological differences. Therefore, control variables had to be used. As expected, countries that have more forestland tend to be more corrupt, while the level of shadow economy seems to not be influenced by this. Nevertheless, the amount of cut trees (in both absolute and relative terms) is influenced by the level of economic and financial crime in a country (in both levels of corruption and shadow economy), but not by the total forestland a country possesses.

Tourism is presented as an alternative, but sustainable solution to exploiting the forestlands. By comparing Romania to Austria, tourism proves to be an effective, long-term, durable activity for counties that are not engaged in illegal affairs, but which are interested in the well-being of their nation. Tourism is not a compromise, but quite the contrary. Tourism can be durable, profitable in the short-term, middle term and long-term for all stakeholders, and friendly with the environment. The only downside is that the bribery for senior civil servants will decrease - and that is where the shift in the paradigm must come from. National tourism branding plays a huge role in the touristic development of a country and the political stage has a big say in this.

The availability of data, the changes in methodology for measuring the indicators, the slow update of the databases, and the differences in constructing datasets are limitations of the study, resulting in small number of observation when taking into consideration more variables. Further research might focus on improving the models by introducing new significant variables and raising the adjusted R-squared, in order to explain a higher percentage of the dependent's variability. Therefore, the phenomenon can be better explained, understood and proven.

\section{References}

Cojocea, L.M. and Coroș, M.M., 2013. The Romanian Hotel Industry. An Analysis Based on Real Facts. Journal of tourism - studies and research in tourism/Revista de turism - studii și cercetări în turism, 16, pp.22-31.

Coroș, M.M., 2015. Managementul cererii și ofertei turistice. București: C.H. Beck.

Coroș, M.M., Pop, C. and Micu (Tăuțan), D.R., 2015. Romania's Unclassified Tourist Inns - A Spark of Rural Authenticity?!/Hanurile turistice neclasificate ale României - o scânteie de autenticitate in turismul rural?!. Iași: PIM.

Coroș, M.M., Pop, C. and Micu (Tăuțan), D.R., 2015. Tourist Inns on Romania's Modern Tourism Market. Studia Universitatis Babes-Bolyai, LX(3), pp.23-50.

Dao, T.V., 2017. Tourism, Poverty Alleviation, and the Informal Economy: The Street Vendors of Hanoi, Vietnam. Tourism Recreation Research, 43(1), pp.52-67.

Davidescu, A., 2014. Revisiting the relationship between unemployment rates and shadow economy. A Toda-Yamamoto approach for the case of Romania. s.1.: Elsevier.

Din, B.H., Habibullah, M.S., Baharom, A.H. and Saari, M.D., 2016. Are shadow economy and tourism Related? International evidence. Procedia Economics and Finance, 35, pp.173-178. 
Economica.net, 2016. Peste 1.000 de agenţii de turism nu mai au licenţă. Printre ele, agenţiile unui fost şef la Turism şi a Bisericii Ortodoxe, [online] Available at: $<$ https://www.economica.net/peste1-000-de-agentii-de-turism-nu-mai-au-licenta-printre-ele-agentiile-unui-fost-sef-la-turism-si-abisericii-ortodoxe_130672.html> [Accessed 3 April 2021].

European Parliament. Directorate General Internal Policies of the Union, 2007. Standardiszation and Quality labels for EU Tourist Service. Notes (IP/B/TRAN/IC/2007-006). [pdf] Available at: $<$ chromeextension://oemmndcbldboiebfnladdacbdfmadadm/https:/www.europarl.europa.eu/RegData/etud es/etudes/join/2007/379230/IPOL-TRAN_ET(2007)379230_EN.pdf $>$ [Accessed 3 April 2021].

Florea, M., Jurca, M., Giurgiu, A. and Dobre, T., 2017. Propunere: Ghizii locali, protejaţi de Poliţia turistică [Interview] (18 September 2017).

HoReCa, 2012. Pensiunile românești nu au învățat 'lecția' clasificării, [online] Available at: $<$ https://www.horeca.ro/ospitalitate/2339-pensiunile-romanesti-nu-au-invatat-lectiaclasificarii.html>

[Accessed 3 April 2021].

Jaliu, D.D. and Răvar, A.S., 2019. Informal Tourism Economy and EU Funding: The Case of Romania. In: Yellow Tourism. Crime and Corruption in the Holiday Sector. s.1.: Springer International Publishing.

Kelmanson, B. et al., 2019. Explaining the Shadow Economy in Europe: Size, Causes and Policy Options (IMF Working Paper - WP/19/278), s.1.: International Monetary Fund (IMF).

Mirus, R. and Smith, R.S., 1997. Canada's Underground Economy: Measurement and Implications. In: O. Lippert \& M. Walker, eds. The Underground Economy: Global Evidence of its Size and Impact. Vancouver: The Fraser Institute.

Mitchell, J., 2010. An Unconventional but Essential Marriage: Pro-Poor Tourism and the Mainstream Industry. Private Sector and Development, 7, pp.3-6.

Popa, A. et al., 2016. The Informal Economy in the Republic of Moldova: a Comprehensive Review, s.1.: International Labour Organization.

Rogerson, C., 2014. Informal Sector Business Tourism and Pro-poor Tourism: Africa's Migrant Entrepreneurs. Mediterranean Journal of Social Sciences, 5(16), pp.153-161.

Schneider, F. and Enste, D., 2002. Hiding in the shadows: the growth of the underground economy. Economic issues. Washington, D.C: International Monetary Fund.

The World Bank Group, 2017. Anti-Corruptionin Romania. The Way Forward (Report No AUS0000008. Danvers, MA: Clearance Center, Inc.

Transparency International, 2021a. Transparency International, Country Data: Romania, [online] Available at: <https://www.transparency.org/en/countries/romania > [Accessed 3 April 2021].

Transparency International, 2021b. Corruption Perceptions Index (CPI) 2020. [pdf] Available at: $<$ https://images.transparencycdn.org/images/CPI2020_Report_EN_0802-WEB-1_2021-02-08103053.pdf $>$ [Accessed 10 April 2021].

United Nations \& World Tourism Organization, 1994. Recommendations on Tourism Statistics 1993. [pdf] Available at: <http://unstats.un.org/unsd/publication/Seriesm/SeriesM_83e.pdf $>$ [Accessed 3 April 2021]. 